\title{
CUSTOMER RELATIONSHIP MANAGEMENT (CRM) ANALYSIS AT A PETROCHEMICAL COMPANY
}

\author{
Vidila Rosalina ${ }^{1}$, Muhammad Natsir ${ }^{2}$, Andri Suhendarsah ${ }^{3}$ \\ Fakultas Teknologi Informasi, Universitas Serang Raya \\ Jl. Raya Cilegon-Serang Taman Kopassus, Serang, Banten, Indonesia \\ ${ }^{1}$ vidila.suhendarsahegmail.com
}

\begin{abstract}
Customer Relationship Management (CRM) has proved a very important contribution to the formation of brand equity and brand value of a company. Using a CRM, the company will know what is expected and required their customers, so it can create a good cooperation. This research was conducted at the petrochemical company PT.Lottechem, Tbk. This research used system modelling by Zachman framework to obtain a complete condition from the company. This Zachman framework can distinguish between data, process, network, people, time and motivation. Modeling systems Customer Relationship Management (CRM) modelling system used Unified Modelling Language (UML) modelling. This research produced Customer Relationship Management (CRM) model system that used for. Analysis Of Needs That Must Be Prioritized for CRM calculates weighting using SAW (Simple Additive Weight) from data, process, user, infrastructure requirements based on technology readiness criteria, investment and human resources. This analysis will be used as a reference in implementation CRM system the petrochemical company.
\end{abstract}

\section{Keywords - CRM, Petrochemicals, System, Zachman} Framework

\section{INTRODUCTION}

In an effort to retain customers or acquire new customers, companies need a proper strategy . One concept that is offered is a CRM ( Customer Relationship Management ) as an integrated function of customer service which aims to enhance customer satisfaction and especially to obtain, maintain, and increase the number of enterprise customers. The concept of CRM is growing along with the change in focus from product centric companies become customer focused [1].

PT . Lottechem, Tbk . themselves facing various obstacles in connection with the Customer handling, ranging from customer data management to operational activities associated with the customer, ie the sample request, the trial customer, customer grouping , customer complaint, and customer satisfaction. CRM system is not yet resulted in the use of human resources and time in completing operational activities associated with the customer to be inefficient and thus the risk of losing the customer becomes larger .
One effort to address the needs that are expected to push the company to serve its customers better again is to implement a CRM system which is an integrated information system that is used to plan, schedule and control the presales activities and postsales within an organization to improve customer satisfaction. CRM is a dynamic process in regulating the relationship between the customer and the company so that the customer can choose to continue the mutually beneficial commercial relationships and to anticipate that the relationship does not become unprofitable enterprises [2] . CRM is not the only key to success in providing the best service, but as a CRM solution will provide greater convenience and improved quality of service to customers and CRM is not a technology solution, but rather a business solution that is supported by technology . PT . Lottechem, Tbk . applying CRM concepts for the purpose of business solutions that are supported by information technology. With the implementation of CRM , companies can provide a wide range of convenience and improved quality of service to its customers. And from petrochemical company itself can increase the effectiveness of the use of human resources and time in completing operational activities associated with the customer. CRM is a sales, marketing and service of integrated [3].

\section{METHOD}

The development of information technology demanded information system development which has an architecture that can provide a representative picture of the above elements of information in an organization. Information architecture is the comprehensive construction of a model of the data, business processes, and information technology assets within the enterprise. Information Architecture presents a long-term view of the various processes, systems, and technologies that are based on a consistent and coherent design so that individual projects can generate a capability not only meets the needs instantly. An information architecture framework linking organizational missions, objectives, and goals of information architecture linking organizational missions, goals, and objectives of the work and the infrastructure needed to implement them .

Zachman Framework illustrates the general architecture of the organization and describe it as a complex enterprise system . Zachman Framework is a popular framework in mapping an 
organization's information architecture. Since its first publication in 1987 , the Zachman Framework has evolved and has become a model in which large organizations from around the world perceive and communicate their company's IT infrastructure. John Zachman the framework it proposes in its application to traditional architecture and engineering ( engineering ), this results in an approach where the form template is made to synthesize two-dimensional framework. The vertical axis provides multiple perspectives on the overall architecture and the horizontal axis to provide a classification of various artifacts in an architecture. Zachman Framework is a comprehensive framework of an information system infrastructure of a company or organization from six perspectives : planner, owner, designer , builder , subcontractor and the working system . There are no hints of the order, the process or the implementation of the framework. Zachman framework is more focused on convincing all aspects of all companies with well organized and clear relationship that will ensure that the system does not have to complete with the sequential application of ( http://zachmaninternational.com/index.php/home-article) .

Minoli briefly explain the main principles that guide the application of the Zachman Framework is :

a) The complete system can be modeled with answer the question: why, who, what, how, where and when .

b) Six perspectives capture all critical methods needed for system development .

c) Restrictions can be added for each perspective : which is further down the line can be added to the above lines to provide the addition of a number of restrictions .

d) The columns represent different abstractions in an effort to reduce the complexity of all the individual models are built .

e) The columns is not a sequence .

f) Each row represents a unique perspective .

g) Each cell is unique . [4]

Zachman Framework is expected to provide a sense of any particular aspect of a system at any viewpoint in the development of the system. This tool can be useful for making decisions about changes and additions. Zachman Framework contains six rows and six columns generate 36 cells or aspects.

The rows of the Zachman Framework include :

a) Scope : dealing with an executive summary for a planner (can be a stakeholder who determine the policy for an organization ) who want an estimate on the size , cost and functionality of an organization .

b) Business models : shows entities and business processes, and how these entities and processes interact with each other c) System Model : used by a systems analyst who must determine the data elements and software functions that represent business model .

d) Technology models : Regarding boundaries tools , technology and materials .

e) Components : represents the individual, independent modules which can be allocated to the contractor for the implementation process .

f) Working the system : the operational display of system

The columns on the Zachman Framework include :

a) Who : represent the relationships within the company The design of the company's organization should relate to the allocation of work and the structure of authority and responsibility .

b) When : relationship represents the time or event that makes performance criteria and quantitative levels for enterprise resources. It is useful for designing schedules , processing architecture , architectural control and timing devices .

c) Why : describe the motivations company. This reflects the goals and objectives, business plans , architectural knowledge and design knowledge .

d) What : describe the entities involved in each perspective of the company . For example, including business objects, system data, relational Tables and definitions .

e) How : show functions in every perspective . For example include business processes, software applications function, the function of computer hardware, and language control loop .

f) Where : shows the locations and interconnections within the company . This includes the main geographic location, a separate section within the logistics network, allocation of system nodes or even memory addresses in the system . [5]

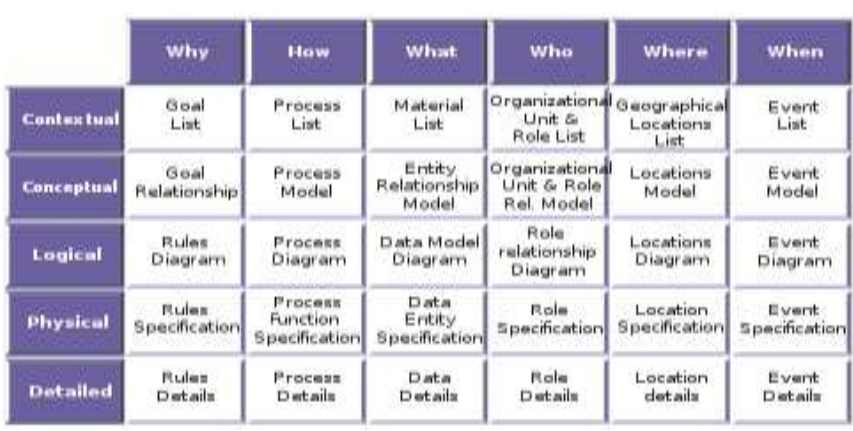

Fig 1. Zachman Framework Model of Cells

(http://www.zachmanframeworkassociates.com/index.php/the-zachmanframework) 


\begin{tabular}{|c|c|c|c|c|c|c|}
\hline $\begin{array}{l}\text { TECHNICAL } \\
\text { ANALYSIS }\end{array}$ & Data & Function & Network & People & Time & $\begin{array}{c}\text { Motivatio } \\
\mathbf{n}\end{array}$ \\
\hline $\begin{array}{c}\text { Scope } \\
\text { (Contextual) }\end{array}$ & $\begin{array}{l}\text { All data } \\
\text { are } \\
\text { needed } \\
\text { on the } \\
\text { system }\end{array}$ & $\begin{array}{c}\text { The } \\
\text { entire } \\
\text { pracess } \\
\text { is } \\
\text { needed } \\
\text { in the } \\
\text { system }\end{array}$ & $\begin{array}{c}\text { Configur } \\
\text { ation of } \\
\text { compute } \\
\Gamma \text { and } \\
\text { compute } \\
\Gamma \\
\text { network }\end{array}$ & $\begin{array}{l}\text { User } \\
\text { which } \\
\text { acts an } \\
\text { the } \\
\text { system }\end{array}$ & $\begin{array}{c}\text { List of } \\
\text { business } \\
\text {-related } \\
\text { events }\end{array}$ & $\begin{array}{l}\text { The scope } \\
\text { of the } \\
\text { work, the } \\
\text { vision and } \\
\text { mission }\end{array}$ \\
\hline $\begin{array}{c}\text { Enterprise } \\
\text { Model } \\
\text { (Conseptual) }\end{array}$ & \multicolumn{6}{|c|}{ Governance system described by Use Case Diagrams } \\
\hline $\begin{array}{c}\text { System } \\
\text { Model } \\
\text { (Logical } \\
\text { Model) }\end{array}$ & $\begin{array}{c}\text { Class } \\
\text { Diagram } \\
\text { (UML) }\end{array}$ & $\begin{array}{c}\text { Activity } \\
\text { Diagram } \\
\text { (UML) }\end{array}$ & $\begin{array}{c}\text { Network } \\
\text { Infrastru } \\
\text { cture }\end{array}$ & $\begin{array}{c}\text { Network } \\
\text { Infrastruc } \\
\text { ture }\end{array}$ & $\begin{array}{c}\text { Sequenc } \\
\text { e } \\
\text { Diagram } \\
\text { (UML) }\end{array}$ & $\begin{array}{c}\text { Objective } \\
\text { System }\end{array}$ \\
\hline $\begin{array}{c}\text { Technology } \\
\text { Model } \\
\text { (Physical) }\end{array}$ & \multicolumn{6}{|c|}{ The design of the user interface } \\
\hline $\begin{array}{l}\text { Representati } \\
\text { on Model }\end{array}$ & \multicolumn{6}{|c|}{ Menus, dialog baxes, stuffing Form } \\
\hline & What & $\overline{H o w}$ & Where & Wha & When & Why \\
\hline
\end{tabular}

Fig 2. Analysis Framework

Zachman Framework does not provide specific models and architectures that can be used to give a full explanation. Zachman Framework users are free to choose the tools that will be used to apply the model to be made. One of the tools that can be used is the UML (Unified Modeling Language). UML is a modeling language to define the visualization, specification, construction, and documenting the artifacts contained in the system. UML allows the systems analyst to create a multi-dimensional models that can be understood by employers, programmers and anyone involved in the development process. UML uses many diagrams to satisfy all points of view or perspective that may arise. Therefore UML can give a good description of the request of the Zachman Framework.

\section{III.RESULT}

System modeling framework of Customer Relationship Management (CRM) in petrochemical companies using Zachman Frameworks can be described:

Based on the above framework, the identification of existing problems in the first stage will diselasaikan define existing problems, then do the analysis and design using the Zachman Framework approach that begins with determining the scope of the system (business scope) that includes all data, processes, users, infrastructure and motivation. The second phase continued with modeling the manufacturing systems is described using the Use Case Diagram and the third stage to
International Journal of Engineering Associates (IJEA) Volume 2 Issue 7 | November 2013 | ISSN 2320-0804

make a model of information system (information system model) in the form of Class Diagram, Activity Diagram and Sequence Diagram.

Here is a restriction problem in the columns of the Zachman Framework modeling of information systems that will be discussed:

Table 1

Zachman Framework

\begin{tabular}{|c|c|l|}
\hline No & Dbjek & \\
\hline 1 & Haw (Proses) & Uraian \\
\hline 2 & What(Data) & List all required data is entered into the system \\
\hline 3 & Who(User) & List all users or users who will use the system \\
\hline 4 & Where(Infrastruktur) & $\begin{array}{l}\text { Explanation network configuration will be } \\
\text { implemented }\end{array}$ \\
\hline 5 & When(Waktu) & $\begin{array}{l}\text { Explanation of the order process is done from } \\
\text { the beginning to the end }\end{array}$ \\
\hline 6 & Why(Motivation) & Explanation of the purpose of the system \\
\hline
\end{tabular}

\section{A. Analysis of Data, Proses, and User Needs}

Analysis of the data needs here is a description of the column What, How, and Who [6]. Data requirements for CRM development in petrochemical companies described in the following table:

Table 1

Table Data Needs

\begin{tabular}{|c|c|c|c|}
\hline No & What (Data) & How (Proses) & Who (User) \\
\hline 1 & User & Login & Admin \\
\hline 2 & Grouplser & Login & Admin \\
\hline 3 & Permissionlser & Login & Admin \\
\hline 4 & Department & Login & Admin \\
\hline 4 & Custamer Profile & Input Data Custamer & Sales Executive (SE) \\
\hline 5 & Custamer Address & Input Data Custamer & Sales Executive (SE) \\
\hline 6 & Custamer Cantact Persan & Input Data Customer & Sales Executive (SE) \\
\hline 7 & Custamer Camment & $\begin{array}{l}\text { Input Data Customer } \\
\text { Profile } \\
\end{array}$ & Sales Executive (SE) \\
\hline 8 & Custamer Purchasing & Input Data Customer & Sales Executive (SE) \\
\hline 9 & Customer Sales Specification & Input Data Custamer & Sales Executive (SE) \\
\hline 10 & Customer Tsc And Sales Visit & Input Custamer Data & Sales Executive (SE) \\
\hline$\|$ & Customer Major & Input Data Customer & Sales Executive (SE) \\
\hline 12 & Sample Request & $\begin{array}{l}\text { Sample Request/ } \\
\text { Permintaan Sampel } \\
\text { untuk Customer }\end{array}$ & $\begin{array}{l}\text { SE/ Technical } \\
\text { Services (TS)/ Head } \\
\text { of Commercial } \\
\text { Official (HCD). } \\
\text { Logistic and Drder } \\
\end{array}$ \\
\hline
\end{tabular}




\begin{tabular}{|c|c|c|c|}
\hline & & & Pracessing (LDP) \\
\hline 13 & Sample Request Detail & $\begin{array}{l}\text { Permintaan Sampel } \\
\text { untuk Customer }\end{array}$ & $\begin{array}{l}\text { SE/ TS/ Head of } \\
\text { Commercial Dfficial } \\
\text { (HCD), Logistic and } \\
\text { Order Processing } \\
\text { (LDP) }\end{array}$ \\
\hline 14 & Custamer Trial Header & Customer Trial & SE/TS \\
\hline 15 & Custamer Trial Detail & Customer Trial & SE/TS \\
\hline I6 & Customer Complaint Header & Custamer Complaint & SE/TS \\
\hline 17 & Customer Complaint Detail & Customer Complaint & SE/TS \\
\hline 18 & Complaint Type & Custamer Complaint & SE/TS \\
\hline 19 & Customer Satisfation & Custamer Satisfation & $\begin{array}{l}\text { SE/ Commercial } \\
\text { Planning (СР) }\end{array}$ \\
\hline 20 & Custamer Group & Custamer Grouping & SE \\
\hline
\end{tabular}

\section{B. Analysis Infrastructure Needs}

Infrastructure needs analysis here is an explanation of the Where column. Necessary infrastructure to handle the data and explain the process in CRM petrochemical companies described in the image below:

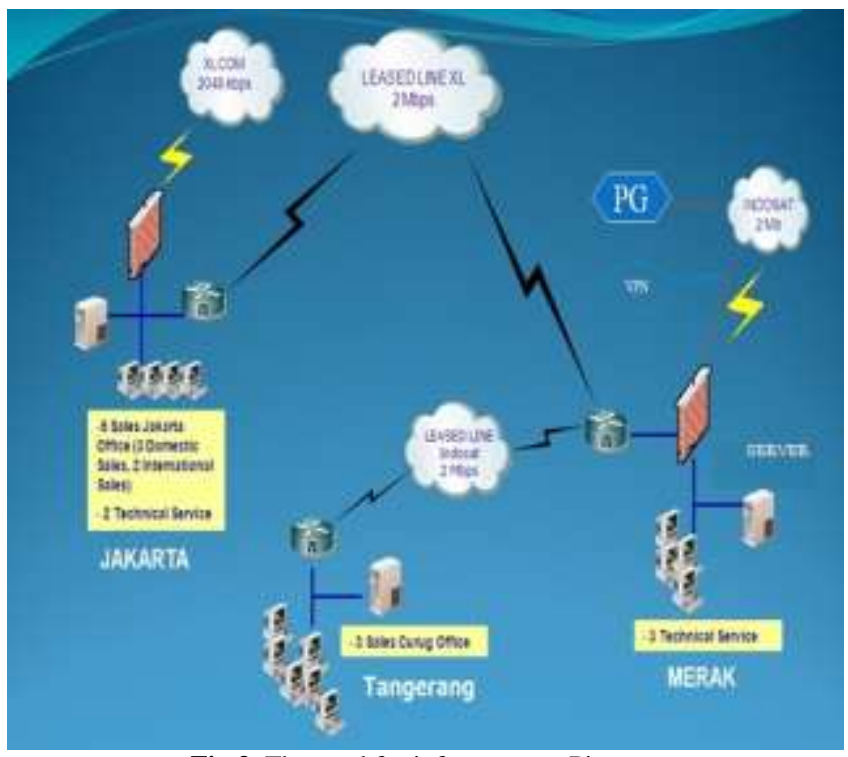

Fig 3. The need for infrastructure Picture

\section{Modeling Using the diagram Usecase}

For Enterprise Model of the CRM system on the Petrochemical companies. using usecase diagrams depicted as follows:

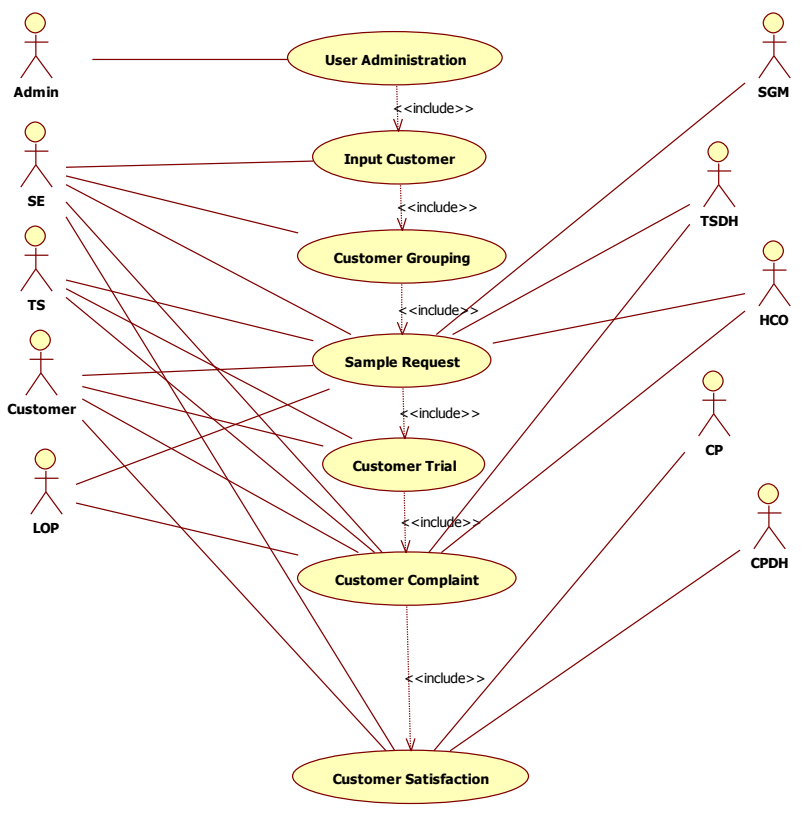

Fig 4. Usecase diagram

Description:

Admin : Administrator

SE : Sales Executive

TS : Technical Service

LOP : Logistics and Order Processing Services

SGM : General Sales Manager

TSDH : Technical Services Department Head

HCO : Head of Commercial Officially

$\mathrm{CP}$ : Commercial Planning

$\mathrm{CPDH}$ : Commercial Planning Department Head

\section{Analysis Of Needs That Must Be Prioritized}

This analysis calculates weighting using SAW (Simple Additive Weight) [7] from data, process, user, infrastructure requirements based on technology readiness criteria, investment and human resources :

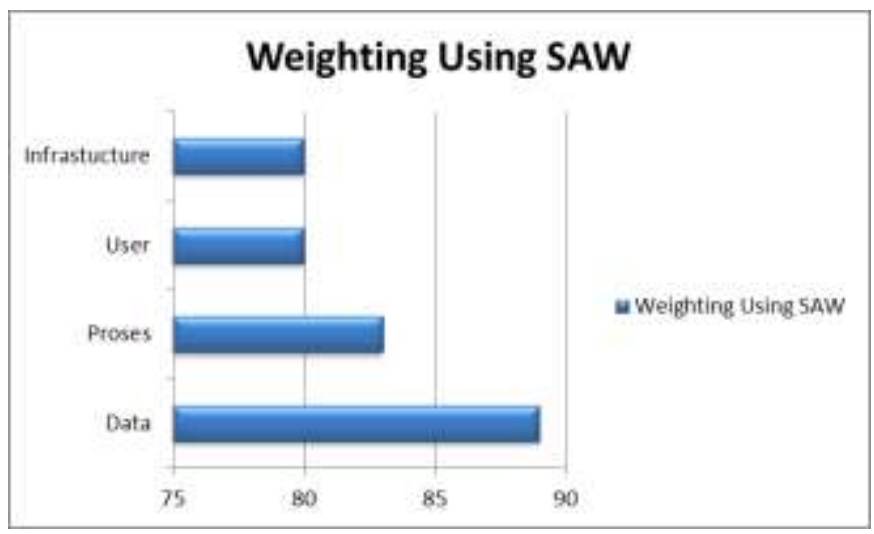

Fig 5. Weigting Of Needs That Must Be Prioritized at Petrochemical Companies

From the calculation above shows that the priority order is data (89), Process (83), User (80), and Infrastructure (80). 


\section{IV.CONCLUSION}

Based on the research that has been done can be concluded that:

a. Needs Analysis Customer Relationship Management system (CRM) at PT . Lottechem, Tbk. begins by modeling the system using the Zachman framework approach to obtain a thorough condition of a company that can separate between the data, processes, infrastructure, people, events and motivation.

b. Modeling Customer Relationship Management system (CRM) at PT . Lottechem, Tbk using modeling techniques UML (Unified Modeling Language) which consists of a Use Case Diagram and Class Diagram for petrochemical companies in handling the operations of customers ranging from sample request, the trial customer, customer complaint, customer grouping to customer satisfaction .

c. Analysis Of Needs That Must Be Prioritized for CRM Implementation calculates weighting using SAW (Simple Additive Weight) from data, process, user, infrastructure requirements based on technology readiness criteria, investment and human resources. From the calculation above shows that the priority order is: data (89), Process (83), User (80), and Infrastructure (80).

\section{REFERENCES}

[1] Zikmund, W., R. McLeod and F. Gilbert (2003): Customer Relationship Management - Integrating Marketing Strategy and Information Technology, John Wiley \& Sons

[2] Bergeron, Bryan (2002), Essentials of CRM: A Guide to Customer Relationship Management. John Wiley \& Sons, Inc., New York, USA

[3] Kalakota, R dan Robinson, Marcia (2001), “ E-Business 2.0 Roadmap for Success" Addsion Wesley Longman Inc, Massachusetts.

[4] Minoli, D., (2008), "Enterprise Architecture A to Z", Boca Raton, CRC Press.

[5] Zifa, Zachman Framework, http://www.zifa.com

[6] Rosalina, Vidila (2013). Pemodelan Customer Relationship Management pada Perusahaan Petrokimia menggunakan Zachman Framework. ELECTRAN Vol 12 (2), 179-191, 2013.

[7] Surbakti, Irfan,(2002), Sistem Pendukung Keputusan (Decision Support System),. Yogyakarta, Graha Ilmu. 